\title{
THE CONSTITUTIONALITY OF THE BANK BILL: THE ATTORNEY GENERAL'S FIRST CONSTITUTIONAL LAW OPINIONS
}

\author{
WALTER Dellinger $\dagger$ AND H. JeFFerson POWELl $\dagger \dagger$
}

From the earliest days of the republic, one of the central responsibilities of the Attorney General of the United States has been to advise officers of the executive branch on questions of law. ${ }^{1}$ In creating the office, the First Congress identified litigation in the Supreme Court and the provision of legal advice as the duties of the Attorney General: the last sentence of section 35 of the Judiciary Act of 1789 states that

there shall also be appointed a meet person, learned in the law, to act as attorney-general for the United States, who shall be sworn or affirmed to a faithful execution of his office; whose duty it shall be to prosecute and conduct all suits in the Supreme Court in which the United States shall be concerned, and to give his advice and opinion upon questions of law when required by the President of the United States, or when requested by the

$\dagger$ Assistant Attorney General, Office of Legal Counsel. United States Department of Justice; Professor of Law (on leave), Duke University.

i† Professor of Law, Duke University (formerly Deputy Assistant Attorney General, Office of Legal Counsel, United States Department of Justice).

The views expressed in this essay are the authors' (or Attorney General Edmund Randolph's!) only and do not necessarily reflect the views of the Department of Justice or of the Office of Legal Counsel. The authors would like to thank Dawn Johnsen, Neil Kinkopf, Herman Marcuse, Dyone Mitchell, and Lawan Robinson.

1. By regulation, the Attorney General has delegated the responsibilities of preparing her formal legal opinions and of providing other forms of legal advice to the assistant attorney general for the Office of Legal Counsel. 28 C.F.R. § 0.25(a) (1993). Since 1977, the Office has also been responsible for publishing the Attorney General's formal opinions as well as selected opinions of its own. See 4A Op. Off. Legal Counsel at v (1980). In a sense, therefore, this Article is the fulfillment of a long-deferred duty. Attorney General Randolph's opinions will also be published in a forthcoming volume of the Opinions of the Office of Legal Counsel. 
heads of any of the departments, touching any matters that may concern their departments, and shall receive such compensation as shall by law be provided. ${ }^{2}$

The modern Attorney General is of course the head of a large governmental department with functions that range far beyond the office's original duties; however, the responsibilities of representing the United States in the Supreme Court and of acting as counsel to the executive branch remain of great importance to the office. ${ }^{3}$ By rendering legal advice to the President and other executive officers, the Attorney General plays an important role in the maintenance of the rule of law. ${ }^{4}$ This role is nowhere more significant than when the Attorney General and the Department of Justice provide advice on the meaning and application of the Constitution. ${ }^{5}$

2. Judiciary Act of 1789 , ch. $20, \S 35,1$ Stat. 73,92 . Since the creation of the Department of Justice in 1870, Act of June 22, 1870, ch. 150, 16 Stat. 162, the Attorney General has also had the constitutional duty, as head of an "executive Department," to provide an "Opinion, in writing" to the President "upon any Subject relating to the Duties of [her] Office." U.S. CONST. art. II, $\S 2$.

3. See 28 U.S.C. $\$ \S 511-513$ (1988) (imposing duty to advise the President, heads of executive departments, and in some circumstances the secretaries of the military departments on questions of law); id. § 518 (requiring Attorney General and Solicitor General to "conduct and argue suits and appeals in the Supreme Court" except where the Attorney General decides otherwise).

4. See generally Douglas W. Kmiec, OLC's Opinion Writing Function: The Legal Adhesive for a Unitary Executive, 15 CARDOzo L. REV. 337 (1993) (describing and surveying the contemporary advice-giving role of the Office of Legal Counsel); John $O$. McGinnis, Models of the Opinion Function of the Attorney General: A Nornative, Descriptive, and Historical Prolegamenon, 15 CARDOZO L. REV. 375 (1993) (outlining models for analyzing the opinion-writing function of the Attorney General and addressing the modern role of the Office of Legal Counsel); Geoffrey P. Miller, The President's Power of Interpretation: Intplications of a Unified Theory of Constitutional Law, LAw \& CONTEMP. PROBS., Autumn 1993, at 35 (discussing the role of the executive branch in constitutional interpretation); Jeremy A. Rabkin, At the President's Side: The Role of the White House Counsel in Constitutional Policy, 15 CARdozo L. REv. 63 (1993) (discussing the role of the White House Counsel in advising the President on legal issues, including a comparison to the role played by the Attorney General); James M. Strine, The Office of Legal Counsel: Legal Professionals in a Political System (1992) (unpublished Ph.D. dissertation, Johns Hopkins University) (discussing the balancing of professional and political values by the Office of Legal Counsel).

5. Indeed, the provision of the 1870 act that first permitted the Attorney General to delegate the duty to provide legal advice did not permit the delegation of opinions "involving a construction of the Constitution of the United States." Act of June 22, 1870, ch. $150, \S 4,16$ Stat. $162,162(1870)$. 
Although the published opinions of the Attorney General include a memorandum from August $1791,{ }^{6}$ they do not include the most important opinion of the first Attorney General, Edmund Randolph. In February 1791, President George Washington asked the views of Randolph, Secretary of State Thomas Jefferson, and Secretary of the Treasury Alexander Hamilton on the constitutionality of a bill to create a national bank that was then awaiting the President's signature or veto. Randolph, who wrote first, actually prepared two memoranda: one setting out his view of the proper legal analysis of the bill's validity, and the other summarizing other arguments that had been made but that he did not find cogent. His conclusion, that Congress lacked the power to grant a corporate charter, was shared by Jefferson and rejected by Hamilton. ${ }^{?}$

Although Washington kept the bank bill opinions confidential, the texts of Hamilton's and Jefferson's opinions eventually became known and by the 1830s had become classic expressions of, respectively, broad and narrow approaches to construing the powers of Congress: they both have been reprinted many times. Randolph's memoranda, written by someone without a political following or an ideological legacy, have languished in apparent obscurity since their appearance in print in $1832 . .^{8}$ This neglect has been a mistake. Randolph, far more than either Hamilton or Jefferson, made a conscious attempt to distinguish his professional judgment about the legal question of constitutionality from his political judgment

6. Interest on Certificates for 1791, 1 Op. Att'y Gen. 2 (1791).

7. The constitutional views of the two secretaries may have been tinctured with their extralegal policy views. Hamilton was the author of the bank bill, a central element in his elaborate legislative agenda. Jefferson, in contrast, was heavily influenced by the "Country" school of political thought that had emerged as the ideology of the political opposition in eighteenth-century Britain. The Country writers identified the Bank of England-the model on which Hamilton had consciously and clearly based the proposed Bank of the United States-as one of the major tools by which "the Court" had corrupted British society and subverted traditional English liberty. See generally LANCE BANNING, The JefFersonian PERSUAsion (1978) (tracing the connections between Country thought and Jeffersonian republicanism).

8. Matthew Clarke and David Hall published all the bank bill opinions in an extensive collection of materials they compiled during the crisis over the rechartering of the Bank of the United States. See Matthew St. Clair Clarke \& David A. Hall, LeGISLATIVE AND DOCUMENTARY HISTORY OF THE BANK OF THE UNITED STATES: INCLUDING THE ORIGINAL BANK OF NORTH AMERICA 86-112 (1832). Clarke and Hall's version of Randolph's opinions is generally accurate but diverges from the manuscripts at various points. 
about the desirability of a national bank. The strengths and weaknesses of his opinions reveal much about the possibility-and the difficulty-of constitutional interpretation as a form of specifically legal (and not merely political) analysis. We therefore have edited for publication Randolph's opinions, which are reprinted below in Part III, as well as his cover letter, reprinted in Part II. Part I outlines the historical background of the opinions and briefly comments on Randolph's understanding and practice of constitutional law.

\section{THE HistoricAl BACKGROUND}

Edmund Randolph had enjoyed a meteoric career up to the time that President George Washington appointed him the first Attorney General of the United States. ${ }^{9}$ A member of one of the most important families in the Virginia gentry, Randolph was virtually the heir to high rank in the colonial legal establishment: his grandfather, uncle, and father were all, in turn, the Crown's attorney general for the colony. ${ }^{10}$ Although his father ultimately resolved conflicting loyalties by retiring to private life in England, Randolph enthusiastically took the colonial side at the outbreak of the Revolution, acting as an aide-de-camp to General George Washington for a few months, before being elected, when not yet twenty-three, to be a delegate to the 1776 convention that adopted Virginia's first constitution and declaration of rights.

Over the next ten years, Randolph served as the state's first attorney general, as a Virginia delegate to the Confederation Congress, and as the governor of Virginia. His experiences played an important role in shaping his later views on the United States Constitution. In 1782, Randolph argued for the state in Commonwealth v. Caton, ${ }^{11}$ a seminal judicial review case. Caton ${ }^{12}$ involved the fate of three loyalists convicted of treason in the Virginia General Court and sentenced to death. The Virginia treason statute provided that pardons for that crime could be granted only

9. For biographical details about Randolph, this Article relies primarily on JOHN J. REARDON, EDMUND RANDOLPH: A BIOGRAPHY (1974).

10. Professor Reardon remarks that by the mid-eighteenth century the legal profession "had come to be identified with [the Randolph] family." Id. at 4 .

11. 8 Va. (4 Call) 5 (1782).

12. This account of the events surrounding the decision in Caton relies on DAvID J. MAYS, EDMUND PENDLETON 1721-1803, at 187-202 (1952). 
by "the general assembly,"13 and so the defendants had applied to the legislature for mercy. The House of Delegates adopted a pardon resolution but the Senate declined to agree. The defendants' argument in the state courts was that the Delegates' resolution alone constituted a valid pardon because the treason statute's apparent requirement of Senate concurrence was contrary to the state constitution. ${ }^{14}$ Arguing as attorney general that the pardon resolution was ineffective, Randolph insisted that the treason statute "pursued the spirit of the constitution" and that "whether it did or not, the court were not authorized to declare it void;",15 in the end a majority of the Virginia Court of Appeals agreed with him that the statute was valid and that consequently the pardon resolution was without effect. ${ }^{16}$ Randolph's correspondence, however, strongly suggests that he personally disagreed with the arguments his position required him to take. ${ }^{17}$ Caton, which Randolph repeatedly described as a "great constitutional question,"18 presented in sharp focus the issues of interpretive method and insti-

13. Act of Oct. 7,1776 , ch. $3, \S 3,9$ Hening's STAtuTES AT LARge 168, 168 (1821).

14. The Virginia Constitution stated that the governor "shall, with the advice of the council of state, have the power of granting reprieves or pardons, except where . . the law shall otherwise particularly direct; in which cases, no reprieve or pardon shall be granted, but by resolve of the house of delegates." VA. CONST. of 1776, para. 6. The treason statute was an apparent exercise of the power to create exceptions by law to the executive's pardoning authority, but by providing for pardons in treason cases by "the general assembly," the statute arguably violated a constitutional requirement that nonexecutive pardons be issued by the House alone.

15. Caton, 8 Va. (4 Call) at 7.

16. After Caton was decided, both houses of the legislature passed a resolution granting a conditional pardon to the defendants: one was required to enlist in the American army, and the other two were required to leave the state until the end of the war. See MAYs, supra note 12 , at 202.

17. See Letter from Edmund Randolph to James Madison (Nov. 8, 1782), in 5 THE PAPERS OF JAMES MADISON 262, 263 (William T. Hutchinson \& William M. E. Rachal eds., 1965) (stating Randolph's opinion that the appeals court's decision upholding the statute was "prude[nt]" but "to any but lawyers the construction, by which the [constitution and statute] were reconcile[d,] would appear unintelligible" (third alteration in original)); Letter from Edmund Randolph to James Madison (July 18, 1782), in 4 THE PA. PERS OF JAMES MADISON, supra, at 422, 424 ("[The treason statute] interchanges with the senate the peculiar rights of the other branch of the legislature."). Professor Reardon concluded that Randolph probably thought that "the court should have ruled against the commonwealth." REARDON, supra note 9, at 63.

18. See, e.g., Letter from Edmund Randolph to James Madison (Nov. 2, 1782), in 5 The PAPERS OF JAMES MADISON, supra note 17, at 230; Letter from Edmund Randolph to James Madison (Oct. 26, 1782), in 5 THE PAPERS OF JAMEs MADison, supra note 17, at 217. 
tutional responsibility that Randolph subsequently faced in advising President Washington on the constitutionality of the bank bill.

Randolph's service in Congress in 1781-1782 forced him to consider not only the meaning of constitutional restrictions on legislative power, but also the specific constitutional issue of what powers the national government could and should exercise, Randolph was the draftsman of the 1781 ordinance by which the Confederation Congress chartered the first national bank, the Bank of North America, as well as the author of a committee report to Congress arguing that such an institution was essential. ${ }^{19}$ Randolph was well aware of the difficulty of finding legal authority for the ordinance in the narrow powers granted Congress under the Articles of Confederation, and he signed a subsequent letter to the governor of Virginia in which the state's congressional delegation explained that Congress's members had approved the ordinance for differing reasons, "some of those, who voted in the affirmative thinking themselves obliged by the engagement in [M]ay [when, prior to adoption of the ordinance, Congress had approved a plan to raise subscriptions for Bank stock], others contending for a constitutional power in these cases, and others assenting to it from absolute necessity."20

Randolph himself seems to have doubted the Confederation Congress's power while believing that the need for a national bank outweighed any constitutional scruples. ${ }^{21}$ The contrast between national need and congressional authority that Randolph encountered in his time in Congress had a profound impact on his political views. By the time he returned home, he had come to share the view held by many young nationalists such as James Madison and Alexander Hamilton that Congress was dangerously weak, and that constitutional reform was necessary to strengthen national authority. ${ }^{22}$

19. See REARDON, supra note 9, at 50-51.

20. Letter from Edmund Randolph, James Madison, and Joseph Jones to Benjamin Harrison (Jan. 8, 1782), in 4 THE PAPERS OF JAMES MADISON, supra note 17, at 18, 19.

21. See REARDON, supra note 9, at 51. In his second 1791 bank bill opinion, Randolph dismissed reliance on the Confederation Congress's action as precedent for the bank bill in terms that support this supposition: "[T] he time of the [1781] incorporation was so pressing, and the states had such an unlimited command over Congress and their acts, that the public acquiescence ought not to be the basis of such a power under the present circumstances." See infra p. 130.

22. "[L]ike so many who served in Congress, he returned to Virginia with a decidedly national outlook." REARDON, supra note 9, at 54 . 
Randolph was a prominent actor in the framing and ratification of the Constitution of $1787 . .^{23}$ His nationalism led him to play a key role in the Annapolis convention of 1786 that served as a dry run for the Philadelphia convention. Randolph's activities at and immediately after the Philadelphia convention, however, were somewhat contradictory. Early in the framing convention he presented the remarkably nationalistic Virginia Plan, and he was a vigorous critic later of the antinationalist counterproposal, the New Jersey Plan. ${ }^{24}$ Randolph declined to sign the Constitution when it was completed, however, and it was only in the Virginia state convention that he openly endorsed ratification. ${ }^{25}$ Randolph's "fickle conduct" with respect to the Constitution earned him much criticism, ${ }^{26}$ which reenforced Randolph's deep-seated dislike for extreme political positions, ${ }^{27}$ but his ultimate-and perhaps decisive $^{28}$-support for ratification in the critical Virginia convention and his prominence among Virginia lawyers made him President Washington's choice for Attorney General.

In his first year in office, Attorney General Randolph had little to do. He was consulted on a few minor matters by executive branch officers, and he was instructed by Congress to prepare a report on the federal judicial system as organized by the 1789 Judiciary Act, an assignment he undertook with enthusiasm. Randolph submitted his report, which suggested major changes in the federal courts, in early $1791,{ }^{29}$ but any interest in judicial re-

23. See id. at 79-86, 96-150.

24. See id. at 98-100, 104-05.

25. When accused of inconsistency, Randolph explained that circumstances had - changed since his initial hesitancy over the Constitution: "[T]he accession of eight States reduced our [i.e., Virginia's] deliberations to the single question of Union or no Union." 10 THE DOCumentaRY History OF THE RATIFICATION OF THE CONSTITUTION 1537, 1537 (John P. Kaminski \& Gaspare J. Saladino eds., 1993) [hereinafter 10 RATIFICATION OF THE CONSTITUTION] (remarks of Randolph at the Virginia convention).

26. See Letter from John Brown Cutting to Thomas Jefferson (July 24, 1788), in 10 RATIFICATION OF THE CONSTITUTION, sipra note 25, at 1707 . Theodorick Bland, an antiFederalist delegate to the Virginia convention, remarked during the convention that Randolph "has at length taken his partie, and appears to be reprobated by the honest on both sides-but is too precious a morsel to be spued out, altho. lukewarm." Letter from Theoderick Bland to Arthur Lee (June 13, 1788), in 10 RATIFICATION OF THE CONSTITUTION, supra note 25 , at $1617,1618$.

27. See ReARDon, supra note 9, at 150.

28. See, e.g., Letter from Martin Oster to Comte de la Luzerne (June 28, 1788), in 10 RAtifiCation OF THE CONSTitution, slipra note 25, at 1689, 1690 ("[Randolph] spoke often and with Eloquence, and his Arguments contributed in no small way to the favorable outcome.").

29. See the important study by Professor Wythe Holt, "Federal Courts as the Asy/um 
form he might have sparked was submerged by the heady debates over Hamilton's national bank bill. The bank bill provided for the creation of a "private" banking corporation, the Bank of the United States, with close links to the federal government. ${ }^{30}$ The Bank's stock would be sold by subscription under the supervision of persons appointed by the President. ${ }^{31}$ Three-fourths of the payments for private subscriptions were to be made in public securities (thus raising the value of the securities instantaneously); the United States, however, was to pay for its subscription (for up to one-fifth of the Bank's capital stock) with a loan from the Bank. ${ }^{32}$ The Bank's notes and bills of credit would be generally negotiable and acceptable as payment for any debts due the federal government, thereby rendering them a de facto circulating medium. $^{33}$ The Bank's directors would be elected by the stockholders (including the United States) rather than appointed by the government, but their operations would be subject to close review by the Secretary of the Treasury. ${ }^{34}$

The passage of the bank bill presented Washington, an extremely cautious man, with a dilemma. ${ }^{35}$ The establishment of a national bank was a central element in Hamilton's legislative program, and Washington shared Hamilton's desire for a strong national government. On the other hand, the bill's chief opponent in Congress was Representative James Madison, a confidant of the President, and Washington was unhappy about the necessity of taking sides in what had become a highly charged political and even partisan controversy. The ideological character of the debate also made involvement in it unattractive to the President. Hamilton and his supporters viewed a national bank as a key element in the construction of a strong, commercially oriented republic. The proposed Bank would stabilize the market value of the government's securities and by doing so play a major role in restoring

to Federal Interests": Randolph's Report, The Benson Amendment, and the "Original Understanding" of the Federal Judiciary, 36 BUFF. L. REV. 341 (1987).

30. Act of Feb. 25, 1791, ch. 10, §§ 1-3, 9-11, 1 Stat. 191, 191-92, 196.

31. Id. § 1,1 Stat. at 191 .

32. Id. \$\& 2, 11, 1 Stat. 192, 196.

33. Id. § 7, para. XIII, 1 Stat. 192, 195; id. § 10, 1 Stat. 196.

34. Id. $\S \S 4,7$, para. XVI, 1 Stat. at 195.

35. For an account of Washington's involvement in the passage of the bank bill, see James T. Flexner, GeOrge Washington and the New NATION (1783-1793), at 277-83 (1969). 
the public credit of the United States, which had evaporated under the feckless Confederation. The Bank's activities in making loans and issuing paper would create the private credit and the circulating medium that Hamilton and his supporters believed the speciestarved United States required for a healthy market economy. The Bank's overall effect, they believed, would be to facilitate governmental operations and forge an unbreakable link between commercial prosperity and the new federal government. The Bank's opponents, by contrast, saw it as a tool of an excessively Anglophile monied aristocracy intent on profit at the expense of republican and agrarian moral values. Madison added to the purely ideological criticism of the Bank a legal dimension when he argued that the bank bill did not rest on any power delegated to Congress by the Constitution. ${ }^{36}$

Randolph agreed with Madison's constitutional conclusion, but not with all of his analysis, ${ }^{37}$ and from a modern perspective the most interesting aspects of Randolph's memoranda are their general comments on constitutional interpretation. Constitutional questions, he suggested, can be properly addressed only if one first understands the nature of the constitution to be interpreted. Where no written constitution exists, the "latitude of power" properly belonging to the government is "not always easy to be determined." Written constitutions (like those of the states) that establish a government but do not specify its powers produce a similar indefiniteness in constitutional debate: the legislature "may perhaps be presumed to be left at large as to all authority which is communicable by the people, and does not affect any of those paramount rights, which a free people cannot be supposed to confide even to their representatives." ${ }^{39}$ The United States Constitution, in contrast, enumerates the powers of the federal government, which therefore can exercise no authority not textually delegated to it. ${ }^{40}$ When the essentially textual source of Congress's

36. The ideological and constitutional dimensions of the 1791 bank bill debate are analyzed in H. JefFerson POWEll, LANGUAGes OF POWER 50-54 (1991); H. Jefferson Powell, The Principles of '98: An Essay in Historical Retrieval, 80 VA. L. REv. 689 , 699-700, 706-12, 722-25 (1994).

37. For a modern edition of Madison's main speech against the bank bill, see JAMES MAdISON, THE BANK BILl (1791), reprinted in 13 THE PAPERS OF JAMES MADISON 372 (Charles F. Hobson \& Robert A. Rutland eds., 1981).

38. See infra p. 122.

39. See infra $\mathrm{pp}$. 122-123.

40. See infra p. 123. 
authority is understood, Randolph insisted, it is clear that Congress's legitimate powers cannot be based on general reasoning about "the nature of the federal government" 41 or the needs of the nation: "While, on the one hand, it ought not to be denied that the federal government superintends the general welfare of the states, it ought not to be forgotten, on the other, that it superintends it according to the dictates of the Constitution." 42

In outlining the "principle[s] of fair construction" 43 applicable to the Constitution, Randolph steered a middle position between advocates of narrow and broad construction of federal power. $\mathrm{He}$ rejected the crabbed view of congressional authority Jefferson expressed in his bank bill opinion ${ }^{44}$ as well as the expansive approach advocated by the supporters of the bank. ${ }^{45}$

The rule therefore for interpreting the specified powers seems to be that, as each of them includes those details which properly constitute the whole of the subject, to which the power relates, the details themselves must be fixed by reasoning. And the ap-

41. See infra p. 122.

42. See infra p. 123. Randolph also rejected related arguments that "Congress may exercise all authority to which the states are individually incompetent," see infra p. 123, and that the general language of the Constitution's Preamble is an independent source of federal power. See infra pp. 125.

43. See infra p. 123.

44. Jefferson reasoned that "[t]o take a single step beyond the boundaries thus specially drawn [by the Tenth Amendment] around the powers of Congress is to take possession of a boundless field of power. no longer susceptible of any definition." THOMAS JEFFERSON, OPINION ON THE CONSTITUTIONALITY OF THE BILL FOR ESTABLISHING A NATIONAL BANK (1791), reprinted in POWELL, supra note 36, at 42 . Therefore, Jefferson thought, the Constitution should be read "to lace [Congress] up straitly within the enumerated powers, and those without which, as means, these powers could not be carried into effect." Id. at 43 . Because the incorporation of a bank was not absolutely necessary to the exercise of Congress's express powers, he concluded, it could not be viewed as an implied power.

45. Hamilton, for example, wrote in his bank bill opinion of "the necessity \& propriety of exercising the authorities intrusted to a government on principles of liberal construction." AleXANDER HaMIlton, OPINION OF THE CONSTITUTIONALITY OF AN ACT to Establish a BanK (1791), reprinted in 8 THE PAPERS OF AlEXANDER HAMILTON 97, 105 (Harold C. Syrett ed., 1965). "If the end [of a statute] be clearly comprehended within any of the specified powers, \& if the measure have an obvious relation to that end, and is not forbidden by any particular provision of the constitution-it may safely be deemed to come within the compass of the national authority." Id. at 107. Because he believed that there was "a natural \& obvious relation between the institution of a bank, and the objects of several of the enumerated powers of the government," id. at 120, Hamilton argued that the bank bill was clearly constitutional. 
peal may, on this occasion be made to common sense and common language. ${ }^{46}$

The bank bill, Randolph thought, was too remote from "the subject" of any of Congress's enumerated powers to be justifiable on the basis of the text of the Constitution. The basic fallacy in the arguments supporting the bill's validity, therefore, was that they emptied the specifications of power in Article I of any limiting force: "[A] similar construction on every specified federal power, will stretch ... into the whole circle of state legislation. ${ }^{\$ 7}$ The "discreet liberallity" with which constitutional powers are to be construed, Randolph insisted, should not be employed so as to undermine the very nature of Congress as a legislature with "partial [rather] than general powers." 48

Randolph's understanding of the scope of legitimate federal authority was overtaken by history long ago-indeed, in a sense, when President Washington decided to sign the bank bill into law despite Randolph's concerns. ${ }^{49}$ Randolph's concern for careful and intellectually honest legal argument, ${ }^{50}$ however, remains of perennial significance. ${ }^{51}$

46. See infra p. 124.

47. See infra p. 126.

48. See infra pp. 123-124.

49. This occasion was thus the first-though not the last-time a President declined to follow the legal advice of the Attorney General or the Office of Legal Counsel.

50. Randolph's unwillingness to endorse arguments supporting his conclusion that others-but not he-found convincing is particularly striking. His second opinion addressed more of the arguments of "the enemies of the bill" than those of its proponents, and he was particularly careful to note the ways in which "the enemies" failed to address the arguments that the bill's supporters actually made. See infra pp. 127-30.

51. Randolph's public career came to an unfortunate end, which may have discouraged interest in his constitutional views. When Jefferson resigned from the cabinet at the end of 1793, Washington appointed Randolph his successor as Secretary of State, and for some time Randolph was the President's closest adviser. In July 1795, however, the British minister turned over a captured French dispatch that suggested that Randolph had disclosed confidential matters to the French minister. On the basis of the dispatch Randolph's enemies in the cabinet accused him of treason and bribery, and unable to explain matters to Washington's satisfaction, he resigned, protesting his innocence but in disgrace. Modern scholars generally agree that Randolph's "relations with the French minister were in no remote sense 'treasonable,' nor was he guilty of having solicited money for himself," but he had been at the least indiscreet, and his service in public office was over. Stanley M. Elkins \& ERIC L. MCKitRick, The AGE of Federalism 426 (1993); see also REARDON, supra note 9, at 307-34 (concluding that Randolph's actions were a wellintentioned but unwise attempt to avoid a rupture in American relations with France). Randolph did play one subsequent role of some significance in the history of the United States Constitution, as one of the defense attorneys in the 1807 treason trial of Aaron 


\section{RANDOLPH'S TRANSMITTAL LETTER ${ }^{52}$}

[Attorney General Randolph enclosed a letter of transmittal to President Washington with his opinions.]

To

Philadelphia

Feby 12th 1791

The President of the United States

Sir

I had arranged a couple of animadversions to be transmitted to you, on the expediency of the Bank bill-but after the recollection of the two conversations, which I have had the honor of holding with you on this subject, I am uncertain whether its expediency constitutes a part of your enquiry from me. If it should be your pleasure, that I should enter into this branch of the question, I can accomplish it on the notice of a few hours.

The enclosed observations No. 1 go as far as I am able to discover, to the substance of the dispute. They arise from an examination of the Constitution itself.

There is indeed a minor class of arguments against the bill, which $I$ have received through the public prints \& other sources of communication. There is also an inferior order of arguments in favor of the bill obtained thro' the same channels. Both descriptions are destitute of influence on my mind but lest I may have depreciated them below their value, I have resolved to state them to you in the paper No. 2 .

I have the honor Sir, to be with the greatest respect your mo. obed. servt. Signed, Edmd. Randolph

Burr. See id. at $357-58$.

52. The following transcriptions reproduce as accurately as possible Randolph's handwritten texts, which are preserved in the Washington Papers in the Library of Congress. In accordance with modern historical editing standards, punctuation and capitalization have been regularized. The layout attempts to replicate the appearance of the originals. 


\section{THE OPINIONS}

The Attorney General of the United States in obedience to the order of the President of the United States, has had under consideration the bill, entitled "An Act to incorporate the Subscribers to the Bank of the United States," and reports on it, in point of constitutionality, as follows:

It must be acknowledged that, if any part of the bill does either encounter the Constitution or is not warranted by it, the clause of incorporation is the only one.

The legal properties of this corporation would be:

1st. To have succession untill the 4th of March 1811;

2d. To purchase, receive, \& retain, real and personal property to an amount not exceeding fifteen millions of dollars, including the capital stock;

3d. To sell \& dispose of the property;

4. To sue $\&$ be sued;

5. To have a common seal; and

6. To make by-laws, and do all acts, appertaining to the corporation, under certain restrictions prescribed in the act.

These properties, with different modifications in some instances, belong to all corporations: their importance strikes the eye.

That the power of creating corporations is not expressly given to Congress, is obvious.

If it can be exercised by them, it must be;

1st. because the nature of the federal government implies it; or

$2 \mathrm{~d}$. because it is involved in some of the specified powers of legislation; or

3. because it is necessary and proper to carry into execution some of the specified powers:

1. To be implied in the nature of the federal government would beget a doctrine so indefinite, as to grasp every power.

Governments having no written constitution may perhaps claim a latitude of power not always easy to be determined. Those which have written constitutions are circumscribed by a just interpretation of the words contained in them. Nay farther; a legislature, instituted even by a written constitution, but without a special demarkation of powers, may perhaps be presumed to be left at large as to all authority which is communicable by the people, and does not affect any of those paramount rights, which a free people cannot be supposed to confide even to their representa- 
tives. Essentially otherwise is the condition of a legislature whose powers are described. An example of the former is in the state legislatures; of the latter, in the legislature of the federal government, the characteristic of which has been confessed by Congress, in the twelfth amendment, to be, that it claims no powers which are not delegated to it.

This last observation straitens the federal powers, and opposes an opinion, not unpatronized, that Congress may exercise all authority to which the states are individually incompetent.

If any subject of government, from which the states are not excluded by the Constitution, be beyond their jurisdiction within their own limits, let it be shewn: it cannot be easily conceived.

But what if a subject should really exist? Is the argument less conclusive to say that the states must retain it, because it is not given to the federal government, than that the latter, although limited in itself possesses it, because it is not within the verge of a state constitution? While, on the one hand, it ought not to be denied that the federal government superintends the general welfare of the states, it ought not to be forgotten, on the other, that it superintends it according to the dictates of the Constitution.

The opinion above alluded to can have only one other object, namely, that every institution to which a single state can give efficacy only within its own boundaries, devolves on Congress. But the extravagance of such a position is manifested by a single circumstance, that the cutting of canals thro' two or more states, at the will of Congress, is one of its least consequences.

2. We ask, then, in the second place, whether, upon any principle of fair construction, the specified powers of legislation involve the power of granting charters of incorporation? We say charters of incorporation, without confining the question to the Bank; because the admission of it in that instance is an admission of it in every other, in which Congress may think the use of it equally expedient.

There is a real difference between the rule of interpretation, applied to a law \& a constitution. The one comprises a summary of matter, for the detail of which numberless laws will be necessary; the other is the very detail. The one is therefore to be construed with a discreet liberallity, the other with a closer adherence to the literal meaning.

But when we compare the modes of construing a state and the federal constitution, we are admonished to be stricter with 
regard to the latter, because there is a greater danger of error in defining partial than general powers.

The rule therefore for interpreting the specified powers seems to be that, as each of them includes those details which properly constitute the whole of the subject, to which the power relates, the details themselves must be fixed by reasoning. And the appeal may, on this occasion be made to common sense and common language.

Those powers, then, which bear any analogy to that of incorporation shall be examined separately in their constituent parts; and afterwards in those traits which are urged to have the strongest resemblance to the favorite power.

1. Congress have power to lay \& collect taxes, \&c. The heads of this power are:

1. to ascertain the subject of taxation, \&c.;

2. to declare the quantum of taxation \&c.;

3. to prescribe the mode of collection; and

4. to ordain the manner of accounting for the taxes \&c.

2dly. Congress have also power to borrow money on the credit of the United States. The heads of this power are:

1. to stipulate a sum to be lent;

2. " an interest, or no interest to be paid; and

3. " the time \& manner of repayment, unless the loan be placed on an irredeemable fund.

3. Congress have also power to regulate commerce with foreign nations, among the several states, and with the Indian tribes.

The heads of this power with respect to foreign nations are:

1. to prohibit them or their commodities from our ports;

2. to impose duties on them, where none existed before, or to increase existing duties on them;

3. to subject them to any species of custom house regulations; or

4. to grant them any exemptions or privileges which policy may suggest.

The heads of this power with respect to the several states are little more than to establish the forms of commercial intercourse between them, \& to keep the prohibitions which the Constitution imposes on that intercourse undiminished in their operation; that is, to prevent taxes on imports or exports; preferences to one port over another by any regulation of commerce or revenue; and du- 
ties upon the entering or clearing of the vessels of one state in the ports of another.

The heads of this power with respect to the Indian tribes are:

1. to prohibit the Indians from coming into, or trading within, the United States;

2. to admit them with or without restrictions;

3. to prohibit citizens of the United States from trading with them; or

4. to permit with or without restrictions.

4. Congress have also power to dispose of \& make all needful rules and regulations respecting the territory or other property belonging to the United States. The heads of this power are:

1. to exert an ownership over the territory of the United States, which may be properly called the property of the United States, as is the Western Territory; and to institute a government therein; or

2. to exert an ownership over the other property of the United States.

This property may signify:

1. Personal property of the United States, howsoever acquired; or

2. real property, not aptly denominated territory, acquired by cession or otherwise.

It cannot signify:

1. Debts due from the United States;

2. Nor money arising from the sources of revenue pointed out in the Constitution. The disposal and regulation of money is the final cause for raising it by taxes \&c.

5. The Preamble to the Constitution has also been relied on as a source of power.

To this, it will be here remarked, once for all, that the Preamble if it be operative is a full constitution of itself, and the body of the Constitution is useless; but that it is declarative only of the views of the convention, which they supposed would be best fulfilled by the powers delineated; and that such is the legitimate nature of preambles.

With this analysis of the foregoing specified powers, compare each of the corporate powers and where is the similitude? It lies, say the advocates of the bill, in the power to lay \& collect taxes, \&c.; because it facilitates the payment of them: in that of borrowing money; because it creates an ability to lend; in that of regulat- 
ing commerce, because it increases the medium of circulation, and thus encourages activity $\&$ industry. In that of disposing and regulating property; because the contributions, and the interest of the United States in the Bank, are property of the United States. Of each of these reasons, something will be said in their order.

The incorporation of a bank can facilitate the payment of taxes, only by creating a faculty to pay, or by supplying a deficient medium, or by rendering the transportation of money to the seat of government more convenient. But to lay and collect taxes is, in fact, to demand \& receive a public debt, resting the mode of procuring the money on the resources of the debtors; and, as to its transportation, surely there are many other vehicles besides bank bills.

To borrow money presupposes the accumulation of a fund to be lent; and is secondary to the creation of an ability to lend.

By regulating commerce, in order to increase the medium of circulation, cannot be intended any of the commercial powers designated above; these being very remote from the incorporation of a bank. Nor can it be imagined that it is intended to reach the emission of paper money. What construction remains, by which to regulate commerce, can increase the medium? Only the emission of coin, which is licensed in terms by another clause.

To dispose of or to regulate property, even bank stock itself, is utterly distinct from the incorporation of a bank: for the contributions on which the bank stock arises, go upon the principle that a bank already exists; how else can contributions be made to it?

But, in truth, the serious alarm is in the concentered force of these sentiments. If the laying and collecting of taxes brings with it every thing which, in the opinion of Congress, may facilitate the payment of taxes; if to borrow money sets political speculation loose, to conceive what may create an ability to lend; if to regulate commerce is to range in the boundless mazes of projects for the apparently best scheme to invite from abroad, or to diffuse at home, the precious metals; if to dispose of or to regulate property of the United States, is to incorporate a bank, that stock may be subscribed to it by them, it may without exaggeration be affirmed that a similar construction on every specified federal power, will stretch the arm of Congress into the whole circle of state legislation. 
The general qualities of the federal government, independent of the Constitution and the specified powers, being thus insufficient to uphold the incorporation of a bank, we come to the last enquiry, which has been already anticipated, whether it be sanctified by the power to make all laws which shall be necessary and proper for carrying into execution the powers vested by the Constitution. To be necessary is to be incidental, or in other words may be denominated the natural means of executing a power.

The phrase, "and proper," if it has any meaning, does not enlarge the powers of Congress, but rather restricts them. For no power is to be assumed under the general clause, but such as is not only necessary but proper, or perhaps expedient also. But as the friends to the bill ought not to claim any advantage from this clause, so ought not the enemies to it, to quote the clause as having a restrictive effect: both ought to consider it as among the surplusage which as often proceeds from inattention as caution.

However, let it be propounded as an eternal question to those who build new powers on this clause, whether the latitude of construction which they arrogate will not terminate in an unlimited power in Congress?

In every aspect therefore under which the attorney general can view the act, so far as it incorporates the Bank, he is bound to declare his opinion to be against its constitutionality.

Signed, Edmd. Randolph

February 12th, 1791

No. 2.

The Attorney General, holding it to be his duty to address to the President of the United States, as the grounds of an official opinion, no arguments the truth of which he does not acknowledge, has reserved for this paper several topics, which have more or less influenced the friends \& enemies of the Bank bill; and which ought therefore to be communicated to the President.

1. The enemies of the bill have contended that a rule of construction, adverse to the power of incorporation, springs out of the Constitution itself; that after the grant of certain powers to Congress, the Constitution, as if cautious against usurpation, specially grants several other powers, more akin to those before given, than the incorporation of a bank is to any of those from which it is 
deduced. This position, they say, has been exemplified in four instances:

1. A power is given to regulate commerce; and yet is added a power to establish uniform laws on the subject of bankruptcies throughout the United States; to fix the standard of weights and measures; and to establish post offices and post roads.

2. A power is given to coin money; and yet is added a power to regulate the value thereof and of foreign coin; and to provide for the punishment of counterfeiting the current coin of the United States.

3. A power is given to declare war; \& yet is added a power to grant letters of marque and reprisal; to make rules concerning captures on land \& water; to raise \& support armies; to provide \& maintain a navy; and to make rules for the government \& regulation of the land \& naval forces.

4. A power is given to provide for calling forth the militia, to execute the laws of the Union; and yet is added a power to call them forth to suppress insurrections.

Whosoever will attentively inspect the Constitution will readily perceive the force of what is expressed in the letter of the convention, "That the Constitution was the result of a spirit of amity and mutual deference \& concession." To argue, then, from its style or arrangement, as being logically exact, is perhaps a scheme of reasoning not absolutely precise.

But if the Constitution were ever so perfect, considered even as a composition, the difficulties which the above doctrine has started may be solved by the following remarks.

These similar powers, on which stress is laid, are either incidental or substantive, that is, independent powers.

If they be incidental powers, and the conclusion be that, because some incidental powers are expressed, no others are admissible, it would not only be contrary to the common forms of construction, but would reduce the present Congress to the feebleness of the old one, which could exercise no powers not expressly delegated. So that the advocates for the power of incorporation, on the principle of incidentality to some specified power, would, notwithstanding this supposed rule of interpretation, be as much at liberty to insist on its being an incidental power as ever.

If these similar powers be substantive and independant (as on many occasions they are, that is, as they can be conceived to be capable of being used, independently of what is called the princi- 
pal power) it ought not to be inferred that they were inserted for any other purpose than to bestow an independent power, where it would not otherwise have existed.

The only remaining signification which the doctrine now controverted can have is that the incorporation of a bank, being more wide from a connection with the specified powers of legislation than the additional ones were from the principal powers to which they were supposed to belong, the power of incorporation being omitted, or rather not specially mentioned, cannot be assumed. Even this answer is not adequate to those who derive the power of incorporation from the nature of the federal government.

Hence the rule contended for by the enemies of the bill is defective every way. It would be still more so with respect to those (if any such there be) who construe the words, "necessary and proper," so as to embrace every expedient power.

2. An appeal has been also made by the enemies of the bill to what passed in the federal convention on this subject. But ought not the Constitution to be decided on by the import of its own expressions? What may not be the consequence if an almost unknown history should govern the construction?

3. The opinions too of several respectable characters have been cited, as delivered in the state conventions. As these have no authoritative influence, so ought it to be remembered that observations were uttered by the advocates of the Constitution, before its adoption, to which they will not and, in many cases, ought not to adhere.

4. On the other hand, the friends to the bill have relied on the congressional acts as to West Point, the government of the Western Territory, and the power of removal from office given to the President.

The two first are within express powers, as will occur, by adverting to the power to exercise authority over places purchased for forts \&c. and to the power to dispose of and make needful rules and regulations respecting the property of the Und. States. The last is a point with a great weight of reason on each side. If it be founded on the general nature of executive authority, the power is probably not tenable, without resorting to the doctrines of the friends to the bill. But it appears to be a power not specially given to any person (except on an impeachment) and may therefore incidentally belong to Congress to confer on the President: however, if this step be an error, it is never too late to correct it. 
5. It has been also pretended, that even the infirm old Congress incorporated a bank; and can a less power be presumed to be vested in the federal government which has been formed to remedy their weakness? This argument is so indefinite, the time of the incorporation was so pressing, and the states had such an unlimited command over Congress and their acts, that the public acquiescence ought not to be the basis of such a power under the present circumstances.

6. Congress, it is farther said, may provide for the general welfare, and this includes the power of incorporation: but they are to provide for the general welfare in laying \& collecting taxes. Is the mcorporation of a bank a tax bill? The meaning of the power, taken together, seems to be that Congress may lay taxes for the purpose of expending money for the public welfare, even to subscribe it to a bank. But is this like the creation of [a] bank? It implies that a bank lias been already created.

7. It has been also asserted that Congress have an exclusive legislation at the seat of government. This will not be true until they go to the place of the permanent residence.

The attorney general lias not collected any other information upon this subject, altho' more may perhaps have been said by the partizans for \& against the Bank than is here noticed.

Signed, Edm. Randolph

Feby. 12th, 1791 


\section{APPENDIX: THE BANK BILL-A MODERN OPINION}

If the Office of Legal Counsel were asked today to advise the President as to constitutional issues raised by the bank bill, it would address a quite different set of concerns from those raised by Attorney General Randolph. Congress's constitutional authority to charter a national bank is, of course, a matter of settled and venerable precedent. ${ }^{53}$ What was for Randolph and his contemporaries a difficult and hotly contested constitutional issue would present no difficulties today.

A modern Office of Legal Counsel opinion on the bank bill would, on the other hand, likely identify and address a variety of issues arising from the Appointments Clause ${ }^{54}$ and the principle of separation of powers. ${ }^{55}$ The Appointments Clause, which limits the procedures by which "Officers of the United States" may be appointed, would apply to the Bank only if the Bank were a government entity. To say the least, the Bank had close links with the federal government. ${ }^{56}$ In addition to these links, the states were prohibited from taxing the Bank. ${ }^{57}$ Given these factors, the Bank arguably would have been a government entity. ${ }^{58}$ To conclude that the Appointments Clause was implicated by the bank bill, it would also be necessary to decide that the Bank's directors exercise "significant authority pursuant to the laws of the United States." 59 A vigorous reading of the Bank's authority might lead one to conclude that its directors were to wield such authority.

53. M'Culloch v. Maryland, 17 U.S. (4 Wheat.) 316 (1819). Even if Congress's authority were not so settled, however, the bank bill clearly would be valid under the modern understanding of the Borrowing Clause, U.S. CONST. art $1, \S 8$, cl. 2 , and the commerce and spending powers, U.S. CoNST. art. 1, $\S 8$, cls. 1, 3. See New York v. United States, 112 S. Ct. 2408, 2419 (1992) (discussing the "[Supreme] Court's broad construction of Congress' power under the Commerce and Spending Clauses"); Hudspeth v. Meiville, 127 F.2d 373, 375 (10th Cir. 1941) (interpreting the Borrowing Clause).

54. U.S. CONST. art. II, § 2 .

55. It is illuminating that neither of these concerns was even mentioned by Attorney General Randolph.

56. Cf. First Agric. Nat'l Bank v. State Tax Comm'n, 392 U.S. 339, 355 (1968) (Marshall, J., dissenting) (noting that second national bank "clearly acted as the fiscal agent of the Government").

57. See Osborn v. Bank of the United States, 22 U.S. (9 Wheat.) 738 (1824).

58. See Mercantile Nat'l Bank v. Langdeau, 371 U.S. 555, 558-59 (1963) (holding national banks to be "quasipublic institutions" subject to congressional control).

59. Buckley v. Valeo, 424 U.S. 1, 126 (1975). 
Under such a reading, the bill would be subject to at least two Appointments Clause objections.

The first objection would be that the bank's officers, its directors, were to be appointed by the shareholders. ${ }^{60}$ The Appointments Clause vests the power to appoint "Officers of the United States" in the President, by and with advice and consent of the Senate, or (for "inferior Officers" when Congress so directs) in the President, the courts, or the heads of departments. ${ }^{61}$ Since the Bank's officers were not to be appointed in any of these ways, the Bank's structure would have been unconstitutional if it were considered a government entity. To render the bank bill constitutional, then, the provisions for the selection of the Bank's directors would have had to be changed to conform to the Appointments Clause.

The second Appointments Clause concern that might be raised concerns the bill's provision restricting eligibility to serve as a director to stockholders who are citizens of the United States. ${ }^{62}$ Relying on a broad reading of Justice Kennedy's concurrence in Public Citizen v. United States Department of Justice, ${ }^{63}$ the Office of Legal Counsel has argued in the recent past that it is "impermissible" for Congress to impose "qualifications requirements on principal officers." ${ }^{64}$ However, the controlling caselaw seems to hold that Congress may impose reasonable and relevant qualification requirements as part of its power to establish offices. ${ }^{65}$ While there may be some officers who by nature of their duties are so close to the President as to admit of no reasonable or relevant qualification requirement, the Bank's directors clearly could not be so described, and in light of 1791 fears about foreign financial control of United States institutions, the citizenship requirement for directors seems reasonable.

On the separation of powers front, some might also find constitutionally objectionable the provision of section 9 establishing a

60. Act of Feb. 25, 1791, ch. 10, \& 4, 1 Stat. 191, 192.

61. U.S. CONST. art. II, $\S 2$, cl. 2.

62. $\$ 7,1$ Stat. at 193.

63. 491 U.S. $440,482-89$ (1989).

64. Common Legislative Encroachments on Executive Branch Constitutional Authority, 13 Op. Off. Legal Counsel 299, 301 (1989) (preliminary print).

65. See, e.g., Myers v. United States, 272 U.S. 52, 129 (1926) ("To Congress under its legislative power is given the establishment of offices, the determination of their functions and jurisdiction, the prescribing of reasonable and relevant qualifications and rules of eligibility of appointees."). 
bounty for anyone who informs of a violation of its substantive proscriptions. ${ }^{66}$ It is similar to the qui tam provisions of the False Claims $\mathrm{Act}^{67}$ that have been said to be unconstitutional because, inter alia, they deputize private individuals not subject to the control of the executive branch to litigate on behalf of the United States. Such fragmentation of executive power, it has been argued, impermissibly undermines the President's ability to enforce the laws of the United States and thus violates the Take Care Clause and the primciple of separation of powers. ${ }^{68}$ This argument, however, has never been the official position of the Department of Justice, and we find persuasive the conclusion of recent circuit court decisions that the False Claims Act is valid. ${ }^{69}$

66. § 9,1 Stat. at 196.

67. 31 U.S.C. § 3730 (1988).

68. See Memorandum to Attorney General Dick Thornburgh from Assistant Attorney General William Barr re: Constitutionality of the Qui Tam Provisions of the False Claims Act, 13 Op. Off. Legal Counsel 249, 273-76 (1989) (preliminary print).

69. See, e.g., United States ex rel. Kelly v. Boeing Co., 9 F.3d 743, 757 (9th Cir. 1993). Section 9 of the bank bill, which gave no actual litigation authority to private persons, is even more clearly constitutional. Act of Feb. 25, 1791, ch. 10, § 9, 1 Stat. 191, 196. 